HSE analytical report "The storm of the first weeks: has has the higher education stepped into pandemic reality"], https://ioe.hse.ru/data/2020/05/26/1551527214/ CAO 6(36)_электронный.pdf (Accessed 26 August 2020).

DOI 10.15826/B978-5-7996-3081-2.07

\title{
New Communicative and Expressive Powers in Online and Offline Teaching Russian as a Foreign Language
}

\author{
Martynova Margarita ${ }^{1}$, Nikolenko Elena ${ }^{2}$, Nikolenko Galina ${ }^{3}$ \\ ${ }^{1}$ Moscow State University of Geodezy and Cartography; Plekhanov Russian \\ University of Economics, Moscow, Russia \\ ${ }^{2}$ Moscow State University, Moscow, Russia \\ ${ }^{3}$ Moscow State University, Moscow, Russia \\ Corresponding author: Martynova Margarita, bilingualconnect@mail.ru
}

\begin{abstract}
The article contains the first results of online education of foreign students with various levels of competence in the Russian language (mainly in conditions of the Russian educational environment). On the example of teaching non-native learners with a philological and non-philological focus in a new distant working mode caused by the pandemic, the defined pros and cons of education in a new educational reality are analyzed. Communicative and expressive powers of online and offline education in teaching Russian as a foreign language are viewed in this context.
\end{abstract}

Keywords: on-line teaching, off-line teaching, Russian as a Foreign Language (RFL), on-line communication, social networks

\section{Introduction}

Unfortunately, today we cannot say that the danger of the pandemic has fully passed. But its first wave put all of us regardless countries and continents into unusual conditions of life and activity. According to research data, 400 million students of colleges and universities all over the world moved to a new mode of education [T4 Education]. Specialists in various fields of knowledge agree that the world will not be the same again. Professionals 
continue to discuss which lessons we can learn from the period of time when we had to be in self-isolation and under which possible scenarios will this or that activity develop. Supporters of digitalization of education consider that at the moment the buildings of schools and institutes are not repositories of knowledge [Kak tekhnologii menyayut obrazovanie?]. But we think that they continue to be repositories of educational traditions based on the humanistic component of pedagogical communication. It is interesting that 30 years ago a pandemic would mean termination of educational activity. But today digital technologies, on the one hand, grant us new abilities and saveeducational process, and on the other hand, sharpened existing problems.

During last 15 years we specified in our articles that the educational system and teaching Russian as a foreign language, in particular, are step by step inbuilt into e-format [Nikolenko, 2008; Nikolenko, 2015].And the pandemic came and we had to quickly transit to online education.

"The world will be different after completion of this quarantine history with coronavirus", - considers Evgeny Yamburg, a honored teacher of RF, Doctor of Education, associate member of RAS [Yamburg, 2020]. And we have nothing to do as to agree with a well-known academician.

In this article we would like to view the issues related to teaching Russian as a foreign language. It is clear that it has faced many of the problems that became obvious for all the system of Russian education including higher school. Some of them may be classified as systematic, others as specific. Of course, teaching Russian as a foreign language is worth an independent analysis of the situation of a complete semester in a distant mode, the first in the history of education.

\section{Research methods}

To carry out the research, we used the following research methods:

- analysis and generalization of theoretical materials related to problems of distant education;

- practical control in the course of teaching Russian as a foreign language for various categories of foreign students differing in level of language and specialization (in online and offline education);

- review of materials of Russian and international video conferences on specifics of working in a new digital educational reality;

- participation in webinars on issues of education and teaching foreign languages taking into account online facilities; 
- oral and written interviews with foreign students with various levels of education and future specialties about pros and cons of new forms of lessons;

- generalization and understanding of received results and control at the completion of the first Russian online semester in higher school;

- simulation of a possible educational scenario of beginning (and continuation) of a new academic year taking into account actual approaches to teaching Russian as a foreign language in the digital era in the conditions of a multicultural environment.

Data from "Rossiiskaya gazeta" reveal that over three hundred thousand foreigners (seven per cent of students) from over one hundred and seventy countries study at the moment in Russian higher schools [Rossijskaya gazeta, 2020]. "Russia takes the sixth place in the World by the number of foreign students after the USA, Great Britain, Germany, France and China. At present the share of foreign students in Russian educational institutions is around 7.3\%.

Today we can surely state that this distant semester was rather successful. Students as well as teachers managed the specified tasks: practical training on Russian, lectures, seminars, control works, exams, including state exams, presentation of final papers on the Bachelor's program, presentation of Master's papers, presentation of final papers at the postgraduate stage, and then Open school days, in particular, in MSU named after M. V. Lomonosov for Russians as well as for foreigners, as well as entrance exams, were all held in an online format.

Let's pay more attention to changes which have happened in the educational process and study them from the point of view of teachers and students.

\section{Teachers}

The fact that almost all teachers managed with the online work is an indicator of their competence in digital technologies. "In the modern educational environment rich in educational resources of a new generation, the role of a teacher cardinally changes. New pedagogical competences shall match possibilities of modern tools and technologies" [Nikolenko, 2015].

Many teachers have long ago understood that without competences in the field of informative and communication technologies (ICT) it is impossible to continue working in a modern school as well as in a higher educational institution. In 2008 we founded an international inter institutional seminar on use of ICT in the practice of teaching Russian as a foreign language. Its tasks included wider promotion and implementation of innovative 
ICT achievements in the practice of teaching Russian as a foreign language, generating new level of competences of a professional community of teachers and stimulating scientific practice-focused research.

Seminar tasks were the following:

- information on the newest achievements in the field of ICT used in teaching Russian as a foreign language (theory and practice);

- exchange of experience in teaching Russian as a foreign language in various higher education institutions in Russia and abroad;

- creation of a positive image of institutions where ICT is actively used in teaching Russian as a foreign language in the educational space of Russian and the world;

- cooperation of Chairs of Russian language on issues of managing educational processes using ICT;

- promotion of qualitative educational products created in various institutions with the purpose of their practical use in educational processes by colleagues from other institutions and from other countries [Nikolenko, 2016].

Of course such seminars, advanced training in this sphere as well as practical work in schools and institutions for recent decades when many lectures and seminars were held distantly, played a positive role in the transition to fully distant education but teachers still felt the challenges. At the present time it is impossible to limit yourself to only analogue data media since the format of education has changed a lot. These processes started long before the pandemic and conditions of quarantine, recent events just pushed the transition to a distant form of education. We do not consider distant to be the only appropriate format nowadays. At present it is impossible to replace a "live" teacher and classroom atmosphere, but all of us shall be ready and must work in "digital" conditions without damaging the quality of education.

For a teacher to perform any lessons in the online mode: practical, seminar or lectures, is a difficult work. There are serious problems in the organization of these lessons or lectures. At first, your vocal cords work more, you spend more emotional energy to make students "move", make them to be active during lessons. One thing is performing lessons with "live" students, and another is a lesson using a video connection. This requires special psychological and technical readiness. What do we mean by the psychological readiness of a teacher?

Not all teachers are good with a PC or other gadgets (and this is not always caused by age limits, sometimes young teachers have had to learn new 
forms of work). If our students know modern gadgets from birth (often they could find a cartoon or a game on PC or smartphone when they are not yet able to walk), the teachers as a rule represent another generation that knows the main principles of the operation of such devices, but still have a psychological barrier towards modern devices. As sometimes it is justified: often it happens that at a very important moment the connection failed or problems arose with the audio as well as with video. Moreover, preparation for a lesson online takes much more time than preparation for a usual offline lesson.

If it is a course of lectures, it is necessary to prepare presentations that structure the text of a lecture. In usual conditions availability of presentations is advisable, and in conditions of online education it is a must. If we talk about practical lessons, all the tasks shall be presented on a screen in the form of a presentation. This also requires additional preparation.

Checking of tasks performed by students, including in the course of the lecture, as feedback from a teacher shall be available, takes much more time compared with checking the same tests performed in work-books or on printed sheets.

A teacher shall spend 12-14 hours a day in front of a PC screen, and this is not good for the eyes, at least. Not only for that. Teachers at an initial stage of pre-university training had to work in 24/7 mode, as difference in time and space borders of the main educational process resulted in that students sent their work in non-working hours and contacted teachers for consultation without day-offs.

And finally we feel very well in the auditorium, but are all of us ready to present ourselves to the students in a video lesson? In other words, are we ready not to be afraid of "detail shots". Perhaps this was the reason why many colleagues refused to use cameras during lessons and did not require that from students. But this make the possibilities of non- educational communication more shallow.

On the other hand, many students also refuse to turn on the camera during lessons. Sometimes it is caused by worsening of connection quality due to increase of total traffic, sometimes - by the unwillingness of student to actively work during lessons. Therefore, the teacher cannot always understand if students really present during the lesson, and if students just joined the conference and do what they want to. In addition, a teacher shall spend much more time to ask students, as not all of them actively react the questions and participate in the lesson. When a teacher is in the classroom, he has 
a visual contact with all the students, and he understands if he has managed to give the information to the students, if they understand the lesson. During online lessons you cannot see the class as a whole, in fact, each student works individually: students do not interact with each other as it usually happens during work in the class.

Please, do not forget about the interior in our virtual auditorium. It is also binding: our appearance as well as our working place shall correspond to the moment - the performance of lessons. We shall remember that we shall combine our professional need of online education with comfort of other family members, etc.

Let's note positive elements of distant education. The most important is that you shall not spend time and effort on the way to the university and back. We shall note that this advantage was mostly for teaching staff, as many foreign students live in dormitories that are near their university. The second positive element is that the distant format makes teachers constantly improve their ICT skills. The online format, as we consider, requires a specific technical and methodological support of teachers from the administration of institutions; movement from strict requirements towards a more flexible system of organization and performance of lessons; understanding difficulties of pedagogical work, overload of a teacher during preparation for online trainings and performance of control, i.e. checking of students' papers, etc.

We shall note that if the academic load is similar to the load in the second semester of last year, we have to spend twice or even thrice as much time on the work.

\section{Students}

For most students, transition to distant forms of education was easy because, as we have already mentioned, the digital format is usual for them almost from their birth. They even prefer to communicate virtually, not in reality. But many of them have faced large difficulties.

From the beginning of March when all Russian students studied in classrooms, teachers of Russian as a foreign language started to understand the need to transit to a remote mode with foreign students. This was caused by the fact that some of them, for example, Chinese students, that are the most part of foreign students in Russian institutions at the moment, were not able to return to Russia after New Year holidays due to the quarantine. During a recent Chinese - Russian online conference on the issues of educational 
exchange and cooperation (August 11,2020) they said that because of the epidemiological situation around 18 thousand of Chinese students of Russian institutions and around 18 thousand Russian students may not return to Russia and to China correspondingly. At the same time, they noted that all of them studied distantly in full [MAPRYaL, 2020]. This is one more piece of evidence of preparedness of teachers as well as students to operating in a distant format.

Students that unfortunately were not able to return home had to withstand difficulties of the situation on site. Even if the accommodation conditions are good in a dormitory, isolation, loneliness and impossibility to be with your family is a serious damage caused by the pandemic to foreign students. Thus, it becomes clear that issues of psychological discomfort are added to educational issues of fast forced transition to a new online format of education. Psychological readiness meaning mental regulation of behavior in accordance with specified norms of educational community is one of the key factors of readiness of a foreign student to education in a new educational environment. Such psychological readiness includes:

- ability to organize working (i.e. educational) time;

- ability to settle interaction with a teacher or teachers (depending on the stage of education) as well as with group mates (often with students of different nationalities, religions, cultures, and after pre-university training with Russian students, being in one group with them);

- ability to control one's own work and independently assess its results.

As we have already noted, speaking about adaptation, an unexpected transition to online education has slowed a little formation of psychological readiness to education in a new language environment among foreign students (especially, for pre-university training).

\subsection{Pre-university courses}

It is known that the period of adaptation of foreign students to the conditions of life and education in Russian higher educational institutions is longer than of Russian students that face this stage when they change school educational system to the institutional [Martynova and Un, 2019]. Researchers and practicing teachers noted that in the case with foreigners we consider a necessity of lingo and cultural adaptation. It actively passes during the period of study at pre-university courses. Interference of the pandemic interrupted the planned adaptation process of foreign students which additionally tested their stress resistance. But we shall note that most of the students managed that and successfully finished such an unusual academic year. 
For example, in MSU named after M. V. Lomonosov, and in the Higher School of Economy transition from full program of education to a distant mode was rather smooth. Excellent technical equipping of the institutions all the students were provided with quality Internet and PCs, if necessary played an important role in that.

We can say that the transition process was rather easy for pre-university courses, as Russian is the main studied subject. Students continued working with their teachers under a usual schedule. The only thing that changed was the format (lessons were held in Zoom and Google Classroom), but as we have already said before, it is a usual format of communication for modern students. As for some forms of work with foreign students at the initial stage of education, that were widely used by teachers during the transition to online format with the purpose to make up for the unavailability of real educational communication in the classroom, we may note the following:

- creating groups in WhatsApp, WeChat and activation of their performance for transition of knowledge as well as audio materials (from teacher's side as well as from students' side);

- quick exchange of information regarding group training;

- "opening" personal communication in WhatsApp, WeChat (in addition to group chat) and performance of individual work with each student;

- possibility to perform additional consultations out of the framework of lessons in Zoom, Skype, WhatsApp, WeChat. Selection of communication form depends on technical facilities of a student (video/ audio).

We cannot say that some institutions did not manage in full to prepare for other subjects introduced as a rule in the second semester of pre-university training compared to offline education. We believe that many teachers on various subjects were not fast enough in the transition to new conditions of online education compared to teachers of Russian as a foreign language. We know that many institutions had difficulties with provisioning hardware to students which resulted in hampering the educational process. We consider that in the modern world every student shall have a possibility to use a PC and Internet, as this is a requirement of the times.

But we shall remember that students from the countries of Africa, SouthEast Asia and Latin America mainly study on pre-university courses. Most of them lack resources and at the moment of introducing online education some students did not have laptops or PCs. Many researchers concluded that the pandemic showed how the financial welfare of a student's family may 
influence efficiency and success of educational process. As foreign colleagues said during online-marathon of international pedagogical community, there are still areas in the world where we cannot talk about new educational technologies [T4 Education, 2020].

In our case. the accommodation of foreign students in dormitories partially assisted in the settlement of the identified problem, as sometimes several students were able to use one PC for mutual work, but for example, such a method of team work is not fit for passing exams, as all the students have to perform individual tasks in writing. Talking about specifics of the work of foreign students in dormitories, we shall note unsatisfactory quality of the Internet connection that sometimes was caused by system overload that was not ready for such a flow of users at a time. Moreover, students and teachers say that a parallel lesson of a neighbor made lessons more difficult. In this case technical noise as well as diffusion of student's concentration, bad quality of sound and many diversionary items arose.

The main pros of the transition to online education for students of pre-university courses is that they did not go deep into the environment of foreign language although most of them selected an education experience abroad, in Russia in our case, in order to better learn Russian being among native speakers,

In a story told by one of the Algerian students who remembered beginning his study in Russian in the offline mode (in 2016 he was sent "by order of Ministry of Education of Russia" to pre-university courses of Ural Federal University in Ekaterinburg) we find the following recollection: "For a year we studied Russian. Every day we had two, three, sometimes four pairs. In the second semester some special subjects: the language of maths, physics, informatics were added. We had to learn to understand teachers of a higher school, read texts on a specialty and generate our own. Once a month we visited museums, theaters, excursions, because listening to a teacher differs a lot from communication with ordinary people that do not follow speech tempo and select words". We quoted this student in order to understand our losses caused by the pandemic from the point of view of students' social experience. During the training of foreigners in a language environment, communication in the class as well as outside it is very important for learning cultural information as well as witnessing behavior models of native speakers.

It is interesting that long before the pandemic this student noted active use of technologies "with profit for myself" as one of the positive charac- 
teristics of Russian education. For example, "you may contact a teacher via the Internet or order to settle issues with your education. In Algeria... the Internet is one of the ways to communicate and entertain".

They can say, that in this case due to the pandemic all of us, teachers and students, in full recognized a potential of various digital facilities in the transfer and receipt of knowledge.

A question - how possible and efficient may be a beginning of a new academic year in the format of pre-university courses in an online mode if the threat of quarantine will exist - is still open from the point of view of specialists. This may raise a lot of educational as well as organizational issues. Let's highlight some of them: 1) formation of groups (in work of monolingual groups many difficulties are eliminated, and what shall we do with international groups? It is clear, that in multinational groups a question on the possible time difference in holding lessons arises); 2) selection of educational facilities efficient for distant education; 3 ) use by a teacher of the main methods of online education and readiness to use them in teaching; 4) necessity on knowing an intermediary language even more than in offline education; 5) video contact as well as audio connection, as this combination, video and audio channels, will be more efficient for achieving a more natural educational process. In the opposite case without a picture we will see loss of non-verbal communications; 6) formation and support of motivation to study Russian in the conditions of long-distance cooperation in the group; 7) formation of a group as an educational community that is ready to work together, not as an educational unit; 8) development of comfortable and friendly relations in the team; 9) transition of the usual traditional for of teacher's work on the transfer of national and cultural information in an online format. etc.

We would like to highlight textbooks and educational facilities satisfying the conditions of an online format. First of all, a textbook shall contain a translation in a student's native language (that is preferred by our students from South-East Asia) or to an intermediary language. It is better to use an educational complex with the system of trainers including those on electronic media, not a separate textbook [Martynova and Nikolenko, 2016]. When most of Russian and foreign educational institutions try to find a compromise between online and offline education in a coming academic year, we may note, that some institutions start to stay ahead and offered online format as a main educational channel. For example, State Institute of Russian 
language named after A.S. Pushkin announced admitting foreign students for online education within the framework of electronic pre-university [Obrazovanie na russkom]. Organizers announced the possibility for preparation for entering Russian institutes without termination of education in school or university, without leaving work or country. Beside Russian language, they offer future students a set of subjects necessary for selected direction (humanitarian, economic, medic and biological) and included unto a general curriculum. The program of electronic pre-university matches the main requirements to a similar form of pre-university training. And offered term of education: one or two years. For electronic pre-university courses the term will depend on intensiveness of classes selected by a student, when for offline education a student has a specified structure of pre-university courses with specified number of hours and smooth introduction of other subjects. Time will show if this "experiment" is successful and viable.

It is of interest that an idea about the complete transition of higher education into a digital format, that appeared during a period of work in the online format among some managers of Russian educational institutions, did not receive necessary support neither among most of the teaching staff nor among students.

\subsection{Bachelors and Masters}

The main difficulty of the transition of bachelors and masters to the online format was that students shall study a lot of various courses in comparison with pre-university training. There are also many types of lessons: lectures, seminars, practical trainings. On the last courses of bachelor's and master's program students shall pass state exams and present the Final qualification paper (FQP).

Many lecture courses were transformed into a written form: teachers sent texts of lectures and video presentations, and students performed written tasks on various topics. On full-time study a teacher performed control during colloquiums, and in the online form it is necessary to answer questions in writing. This took a lot of time for students as well as of teachers. Students were not able to perform written tasks on all courses, and moreover they had to write yearly papers of FQP. Students complained that they had to study the material of lectures independently. It was impossible to ask any question to a teacher during a lecture, if something was not clear.

State exams and presentations of FQP were performed in the mode of video conference on Zoom. Students as well as teachers had problems with 
the connection which made the process of passing exams or presentations more stressful. But in general, the format of exams and presentations did not much differ from those in person.

\section{Communicative and expressive powers in educational process}

Placing the communicative and expressive powers of online and offline education in teaching Russian as a foreign language into the title of this article, we were governed by the following:

- firstly, general communication-oriented focus of teaching foreign languages and Russian as a foreign language, in particular;

- secondly, differences identified in the course of online education in comparison with traditional (auditorium, contact) offline format of education;

- thirdly, understanding of increasing organizing, teaching and management role of a teacher in a new mode of studying languages and future profession;

- fourthly, understanding that the teacher is a bearer of communicative and expressive powers of a language especially in the conditions of unavailability of other "live" language contacts due to pandemic and transition to online education.

Tools for supporting interest to studying Russian language, affecting the senses and imagination of foreign students are in the teacher's hands: this is structured construction of speech in the course of pedagogical communication, emotional expression of speech, its intonation variety, etc. In this case we speak not about birth, but on support of interest as the online format appeared in the beginning of a second semester when even starters had already an interest to the language, as we may hope.

Practice of oral communication shows that expression of speech is defined by linguistic as well as extra linguistic factors. As we know, only language units of any level (even a separate noise) as well as non-verbal means (gestures, mimics, pantomimic) may become a means of expression in speech. In our case one of the additional extra linguistic reasons is quarantine caused by COVID. It is clear that the situation that forces teachers and students to stay home was not happy and made everyone nervous by its uncertainty. Teachers had to perform educational process in a planned scope of transferred knowledge and generated tasks, as well as responsibility for stabilizing the psychological condition of students being on a remote access. 
They say that hugs are especially important for primary school-aged children and they lacked direct contact with a teacher during transition to online education [T4 Education, 2020]. But we consider that foreign students coming to receive a future profession in Russia, especially on an initial stage of studying a language, teachers of Russian often act as a member of family, and in offline education that may use many more tools for psychological support: not only "verbal hugs" (N. Formanovskaya) expressing encouragement during a lesson, but have an extra auditorium talk, settle an arising inter personal conflict, etc.

Communicative and expressive powers of speech primarily appear in the teacher's speech, as he, during structuring his communication, independently thinks as an author of a statement based on knowledge and understanding of a subject matter. This makes teacher's speech effective and efficient. Needing to show your personal attitude towards the content of statements also may be deemed a condition of communication expression of speech. The internal assurance of a speaker and the author that their statement is importane, personal involvement into the content gives teacher's speech an emotional color that is more seen in oral form. But during online education teachers had to search for new powers of communicative and expressive means for written assessment of a huge number of students' works that have a creative nature. Of course, scope and content of such works were defined by the level of education as well as students' specialty. As we have noted, on the one hand, during transition to a new format of education there is a need for a higher ratio of home and auditorium work, and on the other hand, teachers received a large burden on assessing performed works by their correctness as well as by their communicative and expressive specifics.

As it was already mentioned, during pedagogical communication relations between a teacher and a student in the process of a continuous educational dialog acting as a speaker and a listener, psychological contact between the sender and the recipient becomes more essential because during a discussion of various issues, interest and motivation shall be available from both sides. It is interesting that experience of online education has highlighted a range of new possibilities to support and increase motivation. An example is independent development of presentations by students of pre-university courses of one of the groups (MIIGAiK) on a free topic. Students may have chosen already studied topics, but most of them used their right of free choice. Amazingly, together with presentations related to "familiar" well- 
known realities (My country, My city, My family) facts of lingo-cultural specifics of the country of the studied language (Russian Mardi-Gras) and names of famous Russians (A. Chekhov, L, Yashin, M. Sharapova) were popular among the students. A student who will go on to study chemistry chose a topic "Great Russian scientists". Another student with an experience on the specialty "Geodesy" selected the Antarctic. Such a variety of subjects gives us ideas on the interest to some topic as well as on the level of Russian. In order to organize feedback to reporters and with the purpose to try communicative and expressive powers of speech the following form of discussion was offered: after demonstrations of each presentation, students asked questions on the content, clarification of facts or details as well as tried to assess the report and highlight positive points. Presentations of students of the 1st and 2nd year of RANHiGS from far- and near-abroad countries (Vietnam, China, Bulgaria, Tajikistan) with a future profession oriented to international relations, were devoted to the topic containing comparable Russian-national elements regardless of the theme of the report, for example, national cuisine or external policy of a country, famous diplomats, etc.

During the unexpected transition to the online format practicing teachers noted that during group training to introduce all students equally into educational (learning) process and organize live communication is more difficult that during trainings in classroom. What is of interest for teachers as well as students is how the latter felt the lack of communication. One of the suggestions given by a graduate from a pedagogical faculty regarding changing further classes to the online mode was about organization of communication: "Specify topics for communication and presentations on those topics in order to promote a discussion between students and that every student shares his opinion" (Mirco, Serbia).

Maria Lebedeva and Daria Rykhanova from Pushkin's Institute share their skills enabling the attracting of foreign students into live online dialog on the studied language. For such purposes, authors suggest using an "environment natural for youth and actual communicative reality" [Lebedeva, Truhanova, 2020]. Having learned what social networks students use, in what groups they are, what bloggers they subscribe to, which genres that they prefer, teachers may widen their knowledge (CV data) about the students as well as use communicative and expressive powers of speech in real communication. The authors suggest creating memes; more actively attracting modern applications, for example, FaceApp, etc, without fearing the enter- 
taining nature of some of them; study panoramas; create cosplays, make their own videos, etc., i. e. they suggest 'packing' materials and knowledge into 'understandable for student' formats creating "native educational materials".

From our point of view such an approach is methodically justified and modern, because often, working with different textbooks and in educational facilities, we noted what distance is felt sometimes between those who develop educational materials and those who use them [Martynova and Nikolenko, 2016]. Moreover, the development of such "classic" educational materials and their editing take sometimes several years. And in the present conditions (and epidemiological situation of COVID first wave confirmed that) mobility, flexibility and ability to quickly move in accordance with the requirements of the environment are highly demanded in the sphere of education.

\section{Conclusion}

Of course, distant education requires a lot of preparation and managing. This is caused by a necessity to switch between various Internet platforms (depending on the requirements of each higher educational institution), creating a complex agenda, review of educational sites and their designation, correction of teaching staff's pedagogy and guiding performance.

It becomes more obvious that mainly people influence the flexibility and results of the educational process. They will play a leading role in the return to normal offline life. We can say that the pandemic and resulting total transition to the online format showed the importance of the human factor in education.

In teaching and learning communication, where a teacher is a leader and main organizer, he strengthens his position on the online format. Using technologies in order to move group education to a new level, a teacher arranges the mutual work of students in a group creating a team. As one of the UNESCO members said at an international conference - Marathon: "These crises returned teachers to the stage" [T4 Education, 2020].

As one of the students from the 1st course said, "all this issue with coronavirus made the world mad and showed how vulnerable the global system is. Also is was obvious how this situation affects a normal person and, in particular, students and teachers who are extremely busy. Flexibility of systems that are impossible to be restructured at their normal operations is of interest. In this case everything changes very fast and in process" (Matey - Bulgaria - RANHiGS). 
In the process of the mandatory overwhelming transition to distant education of all stages of Russian educational space starting from primary school and finishing with higher and post-graduate education, there are followers of total digitalization of education that consider that "the time when online education will fully replace traditional lectures and seminars in classrooms comes soon" [https://m.sibkray.ru]. But the largest part of the academic community consider digital technologies only as one of the educational tools. Students consider the online format as an ability to widen their knowledge and additional reserve to receive enlarged knowledge received on the offline format. Students want long traditions of university education to be kept despite "the changing nature of modern times". And we fully agree with them. Without doubt, technologies change education: EdTech (digitalization of education) is a reality of today, not tomorrow. But noting new modern tendencies in educational space and assessing their pros and cons, we do not want to forget all the good that our 'classic approaches' have offered us.

Of course, use of technologies during the transition of knowledge has a lot of positive elements, among which are: access to knowledge at any time and from any place; availability of education and elimination of age limits providing a desire to learn something new during a person's life ("life-long education"); selection of interactive educational facilities and format of education, i. e. building an independent "educational vector", etc.

We suppose that full transition to online education at all educational levels (school - pre-university education - university education- post-university education) that happened, show the following:

- new technologies have become a part of the educational process everywhere;

- in an emergency, as the pandemic showed, technologies enabled continuation of the educational process without compromising teachers and students;

- new wide abilities have become available in the range of educational facilities;

- exchange of pedagogical experience may be performed actively and with interest: video conferences, webinars, international conferences - marathons lasting over 10 hours and combining teachers from various forms of education from various counties;

- inexhaustibility of pedagogical solutions, a high stress-resistance level of teachers and their ability to adapt to a new educational reality; 
- possibility to vary a specific weight of use of digital technologies in a real educational process during offline education depending on a range of reasons, for example, form of education, future specialty, specific studied material, etc.

- need to combine efforts of teaching staff on creation of a unified base of online materials for work at various stages of education taking into account forms of education and future specialty of students;

- online format of education is not just a transition from a class board to a screen, from a classroom to comfortable home conditions, replacement of paper textbooks with e-ones- this is a necessity in a scenario of completely different professional pedagogical skills and materials;

- dependence of the educational online process on a wide range of reasons: availability of devices of a due quality for students as well as for a teacher, Internet speed level, lesson methodological support, combination of audio and video channels for a more efficient real communication, etc.

- quarantine proved that social networks cannot replace real communication, and computer technologies cannot argue with a teacher as it is he who manages the educational process taking into account a knowledge component of education as well as the physiological condition of a student.

It seems we can make the following conclusion based on the mentioned above: we are for new technologies and are very pleased with the online-format due to which many of us have found new ways for improving our professional knowledge, but we consider online education only as an auxiliary to the main: contact offline education in classrooms. It is interesting that all our foreign students regardless of forms of education, level of Russian, their future specialty, have the same opinion and are eager to return to classrooms to meet their teachers. As one of the foreign students, who studied mostly in the offline format, said that one of his most important assets gained in Russia except for academic knowledge is „culture of professionalism”, that he had learned due to his Russian teachers.

After we fully understood the educational potential of various digital facilities for transfer and receipt of knowledge, we would like to stay in our institutions again, because it is the place of generation and transfer of social experience necessary for foreign students in a new educational environment.

\section{Conflict of Interest}

The authors have no conflict of interest to declare. 


\section{References:}

1. T4 Education - mezhdunarodnaya onlajn-konferenciya dlya uchitelej so vsego mira [International Online Conference for Teachers from All Over the World], https://www.t4event.one/ (Accessed 30 May 2020).

2. Kak tekhnologii menyayut obrazovanie? [How do technologies change education?], https://svetak.ru/blog/kak-tehnologii-menyayut-obrazovanie (Accessed 28 July 2020).

3. E. Y. Nikolenko. Informacionno-kommunikacionnye tekhnologii kak faktor povysheniya effektivnosti obucheniya russkomu yazyku kak inostrannomu. [Information and communication technologies as factor of increasing effectiveness of teaching Russian as a foreign language]. Russkij yazyk i kul'tura v formirovanii edinogo sociokul'turnogo prostranstva Rossii: Materialy I Kongressa ROPRYaL [Russian language and culture in the process of formation the coherent social and cultural space in Russia: Proceedings of the $1^{\text {st }}$ Congress ROPRYaL] in 2 Parts. Izd. dom MIRS SPb, Saint Petersburg, Part 2 (2008), pp. 208-213.

4. E. Y. Nikolenko. Formirovanie sovremennyh kompetencij prepodavatelya RKI: sostoyanie i perspektivy [The development of modern competences of a teacher of RFL: contemporary condition and perspectives]. Russkij yazyk i literatura v prostranstve mirovoj kul'tury: Sbornik statej uchastnikov XIII Kongressa MAPRYaL [Russian language and literature in the field of the world culture: Proceedings of the XIII Congress MAPRYaL], MAPRYaL Granada, Saint Petersburg, Vol. 10 (2015), pp. 758-763.

5. E. Yamburg. Evgenii Yamburg rasskazal o distancionke v moskovskikh shkolakh [E. Yamburg told about distance learning in schools in Moscow] https:// nation-news.ru/515077-evgenii-yamburg-rasskazal-o-distancionke-v-moskovskikhshkolakh-tormazakh-i-kurezakh (Accessed 05 August 2020).

6. Rossijskaya gazeta [Russian newspaper] https://rg.ru/gazeta/rg/2020/07/16. html http://pushkin. institute/news/detail.php? ID=26698\&bx_sender_conversion_id=3089935 (Accessed 27 July 2020).

7. E. Y. Nikolenko. Smart-tekhnologii v formirovanii informacionno-kommunikacionnoj kvalifikacii prepodavatelya RKI [Smart-technologies in the process of formation of information and communication competency of a teacher of RFL]. Aktual'nye problemy obucheniya russkomu yazyku kak inostrannomu i russkomu yazyku kak nerodnomu: Sbornik statej [Relevant problems of teaching Russian as a foreign language and as a not native one: collection of articles]. Izdatel'stvo Moskovskogo gosudarstvennogo oblastnogo universiteta, Moscow (2016), pp. 177-183.

8. MAPRYaL. 40 vuzov i shkol Rossii i Kitaya vstretilis' na onlajn-konferencii [40 Universities and schools in Russia and China attended an online conference] 
(August 11 $\left.1^{\text {th }}, 2020\right)$, https://e.mail.ru/inbox/0:15971559080245447695:0/ (Accessed 11 August 2020).

9. M. A. Martynova, L. G. Yun. K poisku putej adaptacii kitajskih studentov k rossijskim usloviyam obucheniya $\mathrm{v}$ ramkah sovmestnyh programm (lingvosociokul'turnyj aspekt) [The search of ways for Chinese students to adapt to Russian conditions in education in the frame of dual programs (linguistic aspect)]. Vestnik Rossijskogo novogo universiteta. Seriya: Chelovek v sovremennom mire [Bulletin of Russian new university. Series: Human in the contemporary world], № 1 (2019), pp. 126-133.

10. M. A. Martynova, E. Y. Nikolenko. Sovremennye uchebniki russkogo yazyka kak inostrannogo: Problemy i perspektivy [Contemporary manuals of Russian as a foreign language: problems and perspectives]. Journal of Institute for Russian and Altaic studies. Chungbuk National University, № 8 (2016), pp. 107-131.

11. Obrazovanie na russkom [Education in Russian], pushkininstitute.ru https://e.mail.ru/inbox/0:15967968581950153851:0/ (Accessed 08 August 2020).

12. M. Lebedeva, D. Truhanova. 7 sposobov motivirovat' studentov na onlajn-zanyatiyah: memy i dazhe kosplej [7 wayes to motivate students during online classes: memes and even cosplay], https://mel.fm/layfkhaki/8457023-online_motivation?bx_sender_conversion_id=3089935 (Accessed 27 July 2020).

13. https://m.sibkray.ru/news/2127/936046 (Accessed 20 June 2020).

DOI 10.15826/B978-5-7996-3081-2.08

\section{Specifics of Using E-Educational Resources in Teaching Russian as a Foreign Language}

\section{Trocuk Svetlana}

Russian State Hydrometeorological University, St. Petersburg, Russia svetlana.trocuk@mail.ru

Abstract. This article assesses the effectiveness of modern approaches in teaching and studying Russian as a foreign language (Station Rotation, Flipped Classroom). The author reviews the most popular electronic educational resources in teaching and studying Russian as a foreign language, paying particular attention to such two foreign resources, but gaining popularity among 